\title{
Sentidos y subjetividades detrás del discurso: reflexiones sobre las narrativas del exilio producidas en entrevistas orales
}

\author{
Marina Franco \\ Universidad Nacional de General San Martín, \\ Buenos Aires, Argentina
}

\begin{abstract}
Este trabajo presenta algunas reflexiones surgidas del trabajo con testimonios orales de antiguos emigrados políticos argentinos. Se analizan algunas variantes discursivas utilizadas por ellos, sus silencios y "olvidos", las formas de estructuración del relato y aquellos elementos no lingüísticos que caracterizan el encuentro con el entrevistador.

Nos interesa reflexionar sobre cómo esos elementos discursivos son una fuente productora de sentidos sobre el tema del exilio, cómo ciertos problemas de la historia reciente argentina atraviesan esa experiencia y observar la sobrecarga de sentidos que se tensan en el concepto e identidad de "exiliado".

PALABRAs Clave: Argentina, dictadura militar, exilio, historia oral.
\end{abstract}

This piece present some thoughts that have emerged from the work carried out with real testimonies from Argentine political emigrants. It is based on the analysis of some of the discursive variations used by the interviewees, their silences, that which they "forget", their manner of structuring their memories and all those non-linguistic elements that characterised their communication with the interviewer.

There is a special interest in reflecting on how these discursive elements are also a source that can generate meanings on the problem of exile. The analysis of these issues allows us to approach the complexity of the problems that have appeared in recent Argentinean history and the sense overload that encapsulates the concept and identity of the "exiled".

KEYWORDS: Argentine, military dictatorship, exile, oral history.

\section{Introducción $^{1}$}

El objetivo del presente artículo es presentar algunas reflexiones que han surgido a partir del trabajo con testimonios orales actuales de emigrados políticos argentinos de la década de los setenta y ochenta que vivieron en Francia su período de exilio.

1 Agradezco muy especialmente los cuidadosos y ricos comentarios de los evaluadores del Anиario que me permitieron precisar ciertos aspectos e incorporar otras reflexiones. 
El golpe de Estado de 1976 en Argentina originó un régimen de terrorismo de Estado que instauró una represión salvaje como parte de un vasto dispositivo disciplinario de la sociedad, con consecuencias presentes hasta el día de hoy en la sociedad argentina. El sistema represivo puesto en marcha atravesó todos los sectores y prácticas sociales consideradas contestatarias, y dio lugar a un continuo represivo que incluyó asesinatos, desapariciones, torturas, secuestros, encarcelamientos, exilios. En realidad, este régimen continuó, sistematizó y profundizó una serie de políticas represivas ya implementadas previamente desde fines de 1973, bajo el gobierno constitucional de Juan D. Perón, momento en que empezó a operar la organización terrorista de derecha conocida como Triple A (Alianza Anticomunista Argentina) cuyas acciones, de una extrema violencia, dieron origen a las primeras emigraciones políticas de los años setenta. ${ }^{2} \mathrm{El}$ análisis que se expone se refiere a los emigrados políticos, este particular sector afectado por el terrorismo estatal y paraestatal.

El trabajo, cuyas fuentes orales fueron especialmente "construidas" para nuestra investigación - tal es el concepto desde el cual concebimos las entrevistas realizadas-, nos ha permitido observar una serie de elementos internos a la instancia conversacional, que no siempre son explicitados en los resultados empíricos de las investigaciones y que, sin embargo, requieren un análisis detallado y una problemática específica. Nos referimos tanto a los silencios, olvidos y recurrencias que caracterizan las narrativas, como a las formas de estructuración del relato, las posiciones narrativas adoptadas por los hablantes, las variantes discursivas y léxicas utilizadas y aquellos elementos no lingüísticos que caracterizan el proceso comunicativo con el entrevistador.

Desde un punto de vista metodológico - y también ético-, reflexionar sobre estos elementos es esencial para todo investigador. En primer lugar, porque permite comprender mejor la forma en que se produce la narrativa conversacional en la interacción entrevistador-entrevistado. En segundo lugar, porque contribuye a una reflexión atenta sobre el propio lugar del historiador en cuanto co-productor del relato y, por tanto, una vigilancia epistemológica imprescindible sobre su rol como intelectual en la instancia de producción de conocimiento.

Partiendo de este marco metodológico previo, nos interesa reflexionar aquí sobre cómo esos elementos discursivos lingüísticos y no lingüísticos

2 Sobre el funcionamiento de la Triple A y sus orígenes a fines de 1973 véase González Janzen, Ignacio: La triple A, Contrapunto, Buenos Aires, 1983. 
son también una fuente productora de sentidos sobre el problema del exilio. ¿Qué expresa la necesidad casi espontánea de los entrevistados de justificar la obligación de irse del país o la situación de riesgo extremo en la que estaban? ¿Qué concepción del exilio y de la identidad se deduce de los términos habitualmente presentes en los testimonios como "pena", "condena", "privilegio"? ¿Qué silencios recurrentes estructuran las narrativas del exilio? ¿Cuáles son las explicaciones de esos silencios en función de las trayectorias personales, los contextos políticos y su evolución en el tiempo? ¿Qué diferencia existe entre las narrativas de quienes se quedaron en el lugar de emigración (para nuestro caso de estudio: Francia) y las de quienes regresaron a Argentina?

Un primer análisis de estas cuestiones nos permitirá aproximarnos a la complejidad de ciertos problemas del pasado reciente que también atraviesan la historia del exilio en Argentina, así como a la sobrecarga de sentidos que, hasta el día de hoy, se tensan en el concepto y la identidad de "exiliado".

\section{Las formas del recuerdo y del relato en los testimonios orales}

Este trabajo es el resultado del análisis de un corpus de 65 entrevistas realizadas, entre 2002 y 2004, a emigrados políticos argentinos en Francia. De ellos, la mitad regresó a Argentina tras el período dictatorial y la otra mitad reside actualmente en su país de destino.

La emigración política argentina de los años setenta se compuso, de manera general y también para nuestro caso en particular, de gente joven de entre 18 y 30 años, de origen urbano, pertenecientes a estratos de clase media, de niveles socio-culturales medios, altos y profesionales (o posibles de serlo, dado que muchas personas por su edad aún no habían realizado estudios y lo hicieron en el exilio). En el caso de quienes llegaron a Francia, había cierta cantidad de militantes políticos de cuadros medios e inferiores de organizaciones políticas consideradas "revolucionarias", entre ellas, las principales habían sido protagonistas de la lucha armada en el período previo a la salida del país. ${ }^{3}$ Pero también había muchos otros emigrados que

3 Recordemos brevemente que las dos principales organizaciones armadas argentinas eran Montoneros, que si bien provenían del peronismo, rechazaban a Perón, y el PRT-ERP (Partido Revolucionario de los Trabajadores-Ejército Revolucionario del Pueblo), de origen guevarista. Junto a ellas, otros grupos trotskistas y maoístas (algunos no armados como Política Obrera) protagonizaron 
no hacían ningún tipo de militancia política o sindical significativa y que se exiliaron por persecución laboral, profesional (especialmente en el ámbito de la investigación y la cultura), por persecución a sus familiares y personas cercanas, etc. La mitad de las personas entrevistadas tuvo el estatuto legal de refugiado y la otra mitad vivió en Francia con permisos de residencia como estudiantes o trabajadores. ${ }^{4}$

Por consiguiente, nuestras hipótesis de trabajo conciernen sólo a este conjunto entrevistado y, para ciertos aspectos específicos, sólo a aquellos que tuvieron actividad política antes y/o durante el período de exilio. Por tanto, estas reflexiones no abarcarán al conjunto de la emigración política argentina en Francia, ni mucho menos al resto del exilio en otros destinos, aunque eventualmente lo hallado pueda habilitar perspectivas comparativas en esas otras direcciones.

Aunque no podamos revisar aquí los planteamientos de la historia oral, es necesario introducir algunas mínimas observaciones al respecto, con el fin de precisar el marco metodológico desde el cual fueron analizados los testimonios obtenidos..$^{5}$

La entrevista, como documento oral, no es el resultado de una narración del entrevistado (aunque el "contenido" lo narre él) ni de las preguntas del entrevistador (aunque las respuestas estén condicionadas por lo que éste plantee y la relación que proponga), al contrario, es el producto de una relación. En ese sentido, la entrevista es una narrativa conversacional que

varios momentos de violencia política creciente desde fines de los sesenta y especialmente a partir de 1970. El enfrentamiento creciente con las fuerzas de seguridad estatales y paraestatales permitió que las fuerzas armadas y algunos sectores civiles construyeran la imagen del "caos" y la necesidad de "eliminar subversión” como las justificaciones del golpe de Estado de 1976.

4 Sólo una mínima parte de los emigrados políticos argentinos estuvieron en situación de ilegalidad en Francia - o sólo por períodos breves al comienzo de su exilio-, ya que el marco legal de ese país dificultaba la instalación y cualquier forma de actividad regular y cotidiana para quienes no estuvieran insertos legalmente.

5 El término testimonio es polisémico y suele usarse tanto para referirse al carácter jurídico del relato de un testigo como a la narración de experiencias traumáticas transmitidas para informar o para contar su experiencia, así como también alude a las narraciones más tardías con intenciones estéticas o de crónica personal, a las narraciones tomadas por un profesional con intenciones de producir conocimiento, y también a los relatos de testigos protagonistas así como de testigos observadores. La dificultad de definición específica y los debates ideológicos implicados influyen en la decisión de los especialistas de preferir conservar su polisemia e imprecisión, ligada al concepto bíblico de "aquel que porta en sí la presencia" (Voldman, Danièle: "Le témoignage en l'histoire française du temps présent", Bulletin IHTP $N^{\circ} 75$, París, junio 2000, pág. 50); y rechacen el valor político de la distinción entre protagonista en carne propia o no (Jelin, Elizabeth: Los trabajos de la memoria, Siglo XXI, Buenos Aires, 2002, pág. 91). A los propósitos de nuestra investigación, utilizaremos una noción no restrictiva del término para referirnos a la narración de los sujetos entrevistados y también a las narrativas escritas, contemporáneas a la emigración o posteriores. 
sólo se comprende entendiendo las relaciones dentro de esa estructura cerrada que ella representa. ${ }^{6}$ Por tanto, el testimonio de una situación inducida en una entrevista oral no puede ser analizado de la misma manera que un testimonio espontáneo (no solicitado) presente o pasado. ${ }^{7}$

Entre sus grandes aportes, las fuentes orales - tomadas como complemento del documento escrito- permiten acceder a la historia de sectores y grupos que no han dejado documentación escrita, o a ciertos aspectos de la experiencia social difícilmente abordables mediante otras fuentes que no sean la memoria de los testigos. En este último caso y para los aspectos que interesan a nuestro tema, las fuentes orales permiten, por ejemplo, evocar sensaciones, sentimientos y experiencias particulares que están muy ligadas a las representaciones pasadas y presentes del exilio y a la propia imagen que los protagonistas tienen de sí mismos en esa experiencia. De igual manera, los testimonios permiten evocar tensiones y problemas que las fuentes escritas no traslucen, por ejemplo, el documento escrito no permite construir una microsociología del poder y de la dinámica interna de las organizaciones de exiliados como sí lo hacen las fuentes orales. Como señala Phillipe Joutard, el documento escrito racionaliza realidades mucho más confusas, elimina las tensiones y los no-dichos, permite escasamente reconstruir las interacciones y dinámicas subyacentes, expresa consensos que ocultan las diferencias y diversidades. ${ }^{8}$ Así, tensiones que no se vislumbran en el silencio de la fuente escrita $-o$ para las cuales no existen directamente fuentes posibles-, en la fuente oral son reconstruidas explícitamente por el entrevistado, o quedan al descubierto en frases elusivas, sonrisas o gestos de incomodidad.

Recordemos que en las fuentes orales las narrativas obtenidas son memorias presentes y elaboraciones del pasado, por tanto, un testimonio oral dice tanto sobre los hechos como sobre sus significados y sus reelaboraciones a través del tiempo, y lo dice tanto por medio de la palabra como por los silencios, las dudas, las repeticiones, los lapsus, las miradas. Por eso mismo, como veremos en las próximas páginas, el análisis de las experien-

6 Grele, Ronald: "Movimiento sin meta: Problemas metodológicos y teóricos en la historia oral", en Schwarzstein, Dora (comp.): La historia oral, CEAL, Buenos Aires, 1991, pág. 127. Es conversacional por la relación entre entrevistador y entrevistado y narrativa por la forma de exposición. Por tanto, la entrevista debe distinguirse de otros testimonios autobiográficos, biográficos o memorias; se trata de conversaciones, actividades conjuntas organizadas e informadas por las perspectivas históricas de ambos participantes.

7 Jelin, E. : Los trabajos..., págs. 79-93.

8 Joutard, Philippe : Ces voix qui nous viennent du passe, Hachette, Paris, 1983, pág. 168 y ss. 
cias narradas por los antiguos emigrados permite observar las formas en que se fue construyendo - $\mathrm{O}$ no-, a lo largo del tiempo, la propia identificación como "exiliado", y cómo ésta dependió — y aún depende — de los avatares de los procesos sociales y públicos de recuerdo.

El problema central que en general se le ha imputado a la fuente oral es su subjetividad, tanto la del entrevistado como la del entrevistador. En realidad, la primera subjetividad es la del investigador mismo, que presenta un tema de investigación, formula preguntas, guía una entrevista y sus condiciones de desarrollo, representa a una institución, sector social, generación, etc. ${ }^{9}$ Todos estos factores se presentan al entrevistado y condicionan su discurso creando una narrativa $X$, que sería otra en condiciones distintas. Por eso, también nuestra propia intervención condiciona la construcción discursiva sobre el exilio, la posición adoptada por el narrador o los elementos que se omiten. Por ejemplo, es probable que la diferencia generacional entre entrevistador y entrevistado influya para silenciar ciertos elementos y magnificar otros de la experiencia vivida, como detallaremos más adelante.

Existe ya una cierta discusión sobre los testimonios de situaciones traumáticas como las vividas en los campos de concentración o la tortura - en particular los excelentes trabajos de Michael Pollak sobre los sobrevivientes de la Shoah ${ }^{10}$ - , sin embargo casi no hay reflexiones sobre el testimonio del exilio como narrativa de una experiencia traumática particular. Nos referimos al hecho de que el testimonio de la migración no deseada reúne ciertas situaciones comunes y otras específicas: si bien el "grado de trauma" producido por el exilio suele subestimarse en comparación con otras experiencias - como la represión física directa o la muerte de seres cercanos, por ejemplo - , la forma en que una experiencia es vivida es siempre individual y, por tanto, inconmensurable. Así, la ruptura que conlleva dejar el país, los seres queridos y un proyecto de militancia social y política (en sus distintos grados) se presenta muchas veces como un momento de fractura interna muy importante que reaparece en los relatos actuales de los exiliados con todo su peso. En muchos casos, el proceso de reconstrucción individual posterior a la migración aparece como "exitoso"; en cambio, en otros, el "exilio" aparece como una pérdida irrecuperable, el relato parece situarse

9 Joutard, P.: Ces voix..., pág. 194 y ss.

10 Pollak, Michael: L'expérience concentrationnaire. Essai sur le maintien de l'identité sociale, Métailié, Paris, 1990, pág. 183, y también «La gestion de l'indicible», Une identité blesée, Métailié, Paris, 1993, págs. 140-148. 
nostálgicamente en un pasado perdido, idealizado, y la migración es vivida con la añoranza por una vida que fue "robada", que hubiera sido otra. En otros muchos casos, además, la emigración aparece acompañada de experiencias previas de prisión, secuestro, tortura o la muerte de seres cercanos, por tanto, el destierro se conjuga y superpone con otras situaciones traumáticas. A lo largo de nuestra investigación, sin embargo, algunas de las narrativas testimoniales que demostraron una mayor tensión emocional o, directamente, fuertes bloqueos en torno al tema, no correspondían a personas que hubieran vivido alguna forma de represión, sino "sólo" la experiencia del exilio. Por el contrario, otros sujetos afectados por experiencias de tortura, desaparición, cárcel y posterior exilio generaron narrativas con mayor "control emocional" de la experiencia vivida.

Este tipo de variables obligan entonces a preguntarse por el carácter traumático específico de la experiencia del destierro y lo inconmensurable de todo "trauma". Además, ello remite, por un lado, al contexto de silencio que históricamente ha rodeado al exilio de los años setenta hasta la actualidad, dado que desde el período de retorno a la democracia hasta ahora, los emigrados políticos fueron casi ignorados, o considerados figuras "menores" del pasado autoritario, con escasa legitimidad social para relatar su historia. ${ }^{11}$ Por otro lado, también remite al hecho de que estos relatos han sido mucho menos escuchados y reconocidos que otros —en tanto víctimas de la violencia estatal en Argentina- lo que pudo contribuir a la dificultad en la toma de la palabra, y a generar tensiones en los relatos, saturándolos de presupuestos sobre lo decible y lo no decible. Todas las variantes deben ser consideradas a la hora de la escucha e interpretación de estos testimonios y de la valoración del orden simbólico que les es propio y particular.

\section{La posibilidad de hablar}

A lo largo de la investigación, lo primero que advertimos fue la disposición de la mayoría de los entrevistados a hablar y a contar la experiencia de su "exilio".

11 Sobre las narrativas del exilio y su lugar social véase Jensen, Silvina: "Nadie habrá visto esas imágenes, pero existen. A propósito de las memorias del exilio en la Argentina actual”, América Latina Hoy, 34, Salamanca, 2003; también hemos analizado el tema en Franco, Marina: "El exilio argentino, entre la memoria y la historia. Primeras aproximaciones", VIII Jornadas Interescuelas y Departamentos, Salta, septiembre, 2001. 
Esto remite, en primer lugar, a un aspecto individual y psicológico que supone que un individuo puede querer testimoniar por el simple hecho de sentirse "importante" y "reconocido", por el interés que su vida suscita en un investigador, y, por tanto, en la posibilidad de "pasar a la Historia". Sin embargo, más allá de esta explicación de orden general, hay otros procesos específicos que explican esta toma de la palabra como acto voluntario y deseado. ${ }^{12}$

En la esfera pública argentina se asiste hoy a un proceso de reconocimiento social de ese pasado "traumático", ${ }^{13}$ a partir del procesamiento de los responsables de ciertos crímenes, el esclarecimiento del destino de niños apropiados y de una serie de hechos - a los que nos referiremos a continuación - que marcaron un cambio con respecto a la memoria del pasado inmediato. También se asiste a otra transformación importante: una ruptura del silencio sobre los años anteriores a la dictadura militar y, en particular, sobre el tipo de militancia política que dio origen a las organizaciones revolucionarias y a los proyectos de cambio radical por la vía armada.

Uno de los rasgos sobresalientes que acompaña a este fenómeno es la actual explosión de narrativas testimoniales que han aparecido en el espacio público argentino: los medios de comunicación, librerías, conferencias, diversos eventos y una serie de disposiciones políticas específicas generan un nuevo espacio para que numerosos actores que hasta ahora habían guardado silencio sobre el pasado estén dispuestos a contar su experiencia y hacer memoria. ${ }^{14}$

12 Todas estas consideraciones no implican que no hayamos encontrado casos de personas que se negaron a ser entrevistadas; en dos de los casos se trataba de personas residentes en Francia que habían vivido situaciones muy traumáticas de muerte o desaparición de sus respectivas parejas. En uno de ellos, el abandono total de la lengua española es la medida de la inmensa dificultad de elaboración del pasado traumático.

13 El concepto de trauma para referirse a pasados de violencia estatal y colectiva se ha generalizado y banalizado a partir de los estudios sobre la Shoah. Sin embargo, como recuerda el investigador Hugo Vezzetti, su uso extendido corre el riesgo de imponer la idea de una ruptura total y violenta a una sociedad pasiva ante esa situación. En el caso argentino, esto ocultaría la conflictividad social y política preexistente y de larga data. (Vezzetti, Hugo: Pasado y presente. Guerra, dictadura y sociedad en Argentina, Siglo Veintiuno editores, Buenos Aires, 2002, págs. 60-61). Por esa razón, usamos el concepto entrecomillado para referirnos al discurso de los actores o por su expresividad para referirse al período, pero no como concepto ni categoría de análisis, excepto en su valor psicoanalítico como en el apartado precedente.

14 Jelin, E.: Los trabajos...; Vezzetti, Hugo: "Conflictos de la memoria en la Argentina", Lucha Armada, Año 1, n. ${ }^{\circ}$ 1, Buenos Aires, diciembre-febrero 2005, págs. 46-63. (Véase también, Franco, Marina: "Algunas reflexiones sobre la historiografía argentina y la historia reciente de los años '70", Nuevo Topo, Revista de crítica cultural, n. ${ }^{\circ}$ 1, Buenos Aires, septiembre-octubre 2005, págs. 141-164.) 
No obstante, para contextualizar esta situación es necesario tener en cuenta las distintas maneras en que históricamente se ha ido recordando el pasado reciente en Argentina. Ante todo, el momento actual al que nos referimos sobreviene tras un período previo - entre fines de los años ochenta y mediados de los noventa - caracterizado por un "eclipse de la memoria", durante el cual — bajo la presidencia de Carlos Menem- los indultos a varios responsables de lo sucedido en aquella época y la falta de ética demostrada por el gobierno político redujeron el espacio público de los portadores de las memorias del pasado y marcaron una etapa de aislamiento y fragmentación de los organismos de derechos humanos, cuya presencia había sido central en los años previos. ${ }^{15}$

Tras ese "eclipse", a partir de la segunda mitad de los años noventa, se produjeron ciertos cambios que marcaron un nuevo momento en el proceso más general de "recuerdo" del pasado dictatorial. Entre los elementos que posibilitaron esa nueva situación se pueden mencionar: en 1995, el discurso autocrítico del jefe del Ejército, Martín Balza, en el que se reconocían los crímenes cometidos por las Fuerzas Armadas; ese mismo año, las confesiones públicas del capitán Adolfo Scilingo sobre la forma en que se mataron e hicieron desaparecer los cuerpos de los secuestrados y, finalmente, la aparición de la organización HIJOS (Hijos por la Identidad y la Justicia contra el Olvido y el Silencio), que reunió a los hijos de las víctimas del terrorismo de Estado. ${ }^{16}$

El cambio producido logró que se implantaran ciertas modificaciones en los discursos y representaciones sociales sobre ese pasado. Al menos en los sectores más sensibles al tema y en el espectro político progresista, la figura del "desaparecido", hasta entonces evocada como figura moral de "la víctima" —en general caracterizada como "inocente"- fue revisada. Así,

15 Recordemos que, tras la aprobación de las Leyes de Punto Final (1986) y Obediencia Debida (1987) del gobierno radical de Raúl Alfonsín, los decretos de indulto (1989) aprobados por su sucesor peronista, Carlos Menem, completaron un entramado cuyo objetivo era disminuir la responsabilidad legal de las fuerzas militares protagonistas del terrorismo de Estado.

16 Vezzetti, H.: "Conflictos de la memoria...". Sobre las confesiones de Scilingo, véase Verbitsky, Horacio: El vuelo, Planeta, Buenos Aires, 1995; sobre Balza, véase Feld, Claudia: Del estado a la pantalla: Las imágenes del juicio a los ex comandantes en Argentina, Siglo XXI, Buenos Aires, 2002. En cuanto a HIJOS, aunque de cierta manera fueron vistos como el relevo generacional de Madres y Abuelas de Plaza de Mayo, sus políticas de memoria y de búsqueda de la justicia se diferencian tanto por sus estrategias como por una mayor reivindicación de la lucha política y de los ideales de sus padres desaparecidos (al menos un sector de ellos). Véase Fried, Gabriela: "Memorias que insisten: la intersubjetividad de la memoria y los hijos de desaparecidos por la dictadura militar argentina (1976-1983)" en Groppo, Bruno, y Flier, Patricia (comps.): La imposibilidad del olvido. Recorridos de la memoria en Argentina, Chile y Uruguay, Ediciones al Margen, La Plata, 2001, págs. 127-149. 
empezó a recuperarse su identidad, y la de otras víctimas en general, en tanto actores políticos del pasado - $-\mathrm{y}$, en particular, como militantes de grupos revolucionarios, cuya actividad y compromiso con su deber los llevó al trágico destino-, aspecto que hasta hace unos años había sido casi enteramente silenciado. Esta ruptura con la idea ficticia de "inocencia" de los desaparecidos y de otras víctimas, además, se vio estimulada por la aparición de una nueva serie de memorias y testimonios de la represión cuyo objetivo central fue recuperar esa experiencia política junto con la historia de la militancia de los años setenta. ${ }^{17}$ Así, en estas narrativas se observa un fuerte desplazamiento temático y temporal desde el testimonio de la experiencia represiva como eje central de lo que "debe" ser recordado — rasgo propio de las primeras décadas pos-autoritarias - hacia la memoria de la experiencia previa de militancia política de "los setenta" en sí misma. Y ello aparece asociado a la necesidad explícita de los actores de revisar esa etapa, ya sea con el simple objetivo de recordar la experiencia, transmitirla o de reflexionar sobre ella, pensarla críticamente o establecer balances desde diversas posiciones que van del rescate de la utopía o el elogio de la heroicidad a la autocrítica y la condena. ${ }^{18}$

Como señalábamos, el proceso converge en el momento más inmediato en un auténtico estallido de las memorias del pasado, y no sólo de la militancia política, la cárcel, el exilio. Si el fenómeno no es nuevo, sus dimensiones actuales sí lo son. Por un lado, continúa el proceso de "recuerdo" originado a mediados de los noventa. Por el otro, se relaciona con el lugar social que, material y simbólicamente, se abrió a las víctimas y pro-

17 A modo de ejemplo de este nuevo tipo de memorias: en un testimonio de sobrevivientes del campo de concentración de la ESMA se relata la experiencia de militancia política como instancia determinante de la experiencia de desaparición, secuestro y tortura a la que fueron sometidas (Actis, Manu, et al.: Ese infierno, Editorial Sudamericana, Buenos Aires, 2001). También, Anguita, Eduardo, y Caparrós, Martín: La voluntad, Grupo Editorial Norma, Buenos Aires, 1998; Bonasso, Miguel: Diario de un clandestino, Planeta, Buenos Aires, 2000; entre la filmografía reciente: Blaustein, David: Cazadores de utopías [documental], Argentina, 1995, 150 min; Roque, María Inés: Papá Iván [documental], Argentina /México, 2000, 55 min.; Ickowicz, Luisa, y Blaustein, David: Botín de guerra [documental], Argentina, 2000, 118 min.; Carri, Albertina: Los rubios, Argentina, 2003, 89 min.; Arruti, Mariana: Trelew [documental], Argentina, 2003, 98 min. Sobre este nuevo período histórico de la memoria, véase Sonderéguer, María: "Los relatos sobre el pasado reciente en Argentina", Iberoamérica. América Latina - España - Portugal, 1 (nueva época), Iberoamericana Vervuert, Madrid, 2001; Vezzetti, H.: Pasado y presente..., págs. 191-228.

18 Entre muchas narrativas: Organizaciones político-militares. Testimonio de la lucha armada en la Argentina, 1968-1976, de Carlos Flaskamp, 2002; El tren de la victoria de Cristina Zuker, 2003; Perejiles. Los otros montoneros de Adriana Robles, 2004; Las Violetas del paraíso. Una historia montonera, de Sergio Pollastri, 2003; Montoneros. La resistencia después del final, de Marisa Saadi, 2004; la revista Lucha Armada. 
tagonistas del pasado reciente desde el mismo aparato estatal, a partir del gobierno de Néstor Kirchner. Del reconocimiento de la responsabilidad del Estado en la represión ilegal, a la reciente anulación de las leyes de Obediencia Debida y Punto Final (2003), la participación en altísimas funciones públicas de una gran cantidad de antiguos militantes políticos de los años setenta - antiguos emigrados políticos en Francia incluidos-, hasta la transformación de la ESMA —el más terrible de los campos de detención- en un Museo de la Memoria, todas estas políticas estatales otorgan otra legitimidad para que ciertas memorias sean escuchadas. ${ }^{19}$

Como parte del proceso de cambio de esa situación se está produciendo, además, una ampliación del conocimiento público específico sobre la experiencia del "exilio". Y ello, a su vez, tiene una incidencia directa en el reconocimiento-significativo, pero no por eso unívoco- de esa experiencia de destierro como parte de la historia represiva del terrorismo de Estado. En particular, entre los elementos ligados al cambio de contexto político, el dato más indicativo son las actuales discusiones en torno al proyecto de ley de reparación económica para los emigrados políticos..$^{20}$ Esto ha permitido no sólo reinsertar la experiencia del destierro como parte de las prácticas represivas de la dictadura militar, sino que además ha significado el reconocimiento de los exiliados como "víctimas", incluidos ahora en la fila de quienes han sufrido la violencia política y estatal, fila tradicionalmente monopolizada por la figura de los "desaparecidos". En efecto, durante largos años los familiares de desaparecidos fueron casi los únicos testigos "legítimos" aceptados como portadores de la memoria del "pasado traumático". La actual ampliación del espacio posibilita que la situación comience a modificarse, incluyendo otros relatos de otras experiencias, o incluso de las mismas, contadas por otras voces. Es importante recordar que, en este sentido, los exiliados pueden ser testigos claves del pasado: no

19 En su discurso de asunción el presidente Kirchner señalaba que él mismo formaba parte "de una generación diezmada, castigada con numerosas ausencias" (Diario Página 12, 26 de mayo de 2003). Para el aniversario del golpe de Estado el 24 de marzo de 2004 se anunció la creación del Museo de la Memoria en la ESMA, el mismo presidente pidió "perdón en nombre del Estado" y se descolgaron los retratos de los dictadores Videla y Bignone del Colegio militar (Diario Página 12, 25 de marzo de 2004). Tras varios fallos judiciales, las leyes de Obediencia Debida y Punto Final fueron declaradas nulas por la ley en septiembre de 2003.

20 El proyecto de ley, aprobado por el Senado el 2 de marzo de 2005, contempla la reparación económica para quienes debieron salir del país por persecución política probada. Su antecedente directo es un proyecto del año 1998 que no fue aprobado. Aún se debate cómo demostrar el carácter de "exiliado" en los casos en que no se tuvo el estatuto jurídico de refugiado y si la situación de "exilio" es equiparable a la de presos políticos, desaparecidos, etc. 
sólo para recuperar una parte de la experiencia autoritaria que es el destierro en sí mismo, sino también porque como son sobrevivientes de situaciones extremas, se constituyen en testigos únicos, para narrar algo que otros, los muertos, los desaparecidos, ya no pueden contar. ${ }^{21}$

Todo esto ha contribuido a dar una nueva legitimidad a la palabra de los antiguos emigrados políticos y, por tanto, a la aceptación de "narrarse" y de "ser narrado" por parte de los testigos entrevistados, a la toma de conciencia de que en la experiencia del destierro hay algo legítimo de ser transmitido. Como ha señalado Michael Pollak, a partir del trabajo con sobrevivientes de la Shoah, la posibilidad de hablar depende de la posibilidad de ser escuchado. ${ }^{22}$ Así, las transformaciones de la esfera pública argentina en relación con las memorias del pasado reciente están generando - y este es un proceso en evolución permanente- otras condiciones de escucha y recepción para quienes debieron dejar el país en los años setenta y ochenta.

El sentido de la transformación producida queda expresado en las palabras de un intelectual y antiguo exiliado, que resume bien la percepción de los propios emigrados sobre su lugar social hasta hace muy pocos años:

"Finalmente el exiliado también fue un reaparecido que pudo pensar, que pudo acompañar la desdicha de los muertos, que pudo sincronizarse con la conciencia de un tiempo aciago. Que pudo ser un testigo tan fiel como inútil, tan pertrechado como distante de los epicentros del drama, tan relator como inescuchado por nuestra comunidad y sus tumbas NN." ${ }^{23}$

\section{La necesidad de legitimación}

A pesar de estos cambios, la disposición a hablar que hemos registrado tiene también ciertos matices y marcas particulares. Según traslucen las tensiones de las narrativas recogidas, las formas de la escucha social actual siguen modeladas e impregnadas por los avatares de las formas en que se

21 Según Giorgio Agamben, en relación con los sobrevivientes de la Shoah, "el testimonio vale esencialmente por lo que falta", ya que los sobrevivientes hablan por delegación de aquellos "testigos integrales" que son en realidad quienes ya no están para hablar. El testimonio "contiene en su centro mismo algo que es intestimoniable, destruye la autoridad de los sobrevivientes". (Véase Agamben, Giorgio: Lo que queda de Auschwitz. El archivo y el testigo. Homo sacer III, Pre-Textos, Valencia, 1999).

22 Pollak, M.: L'expérience..., pág. 183.

23 Casullo, Nicolás: "Fragmentos de memorias, la transmisión cancelada", en Guelerman, Sergio (comp.): Memorias en presente. Identidad y transmisión en la Argentina posgenocidio, Norma, Buenos Aires, 2001, pág. 215. 
fue "recordando" públicamente en Argentina. De este modo, las representaciones que en el pasado circularon estigmatizando y olvidando el exilio tienen todavía un enorme peso que condiciona y recorta el discurso de nuestros actores entrevistados. Por ejemplo, la necesidad que tienen muchos de ellos de justificar la opción de emigrar o de demostrar el sufrimiento vivido "en el exilio" es el resultado de un imaginario social que durante muchos años condenó a "los que se fueron" y les impuso el "silencio" al no considerarlos "víctimas" del terrorismo de Estado, porque, en definitiva, habían salvado su vida y, peor aún, habían "escapado" a la dura experiencia política y económica de vivir en Argentina bajo la dictadura militar. Por otro lado, en esta necesidad actual de justificación, también está presente el fantasma de la acusación proyectada por los militares argentinos que consideraron a los exiliados como "subversivos" que huyeron al exterior y que vivían "exilios dorados en Europa". ${ }^{4}$ Esta imagen, presente durante largo tiempo en la sociedad argentina, contribuyó no sólo a la estigmatización de los exiliados, sino a aumentar su sentimiento de culpa por los que se quedaron.

Por esto mismo, muchas veces, en los testimonios, la construcción discursiva de una identidad o imagen específica como exiliado resulta tortuosa, cargada de tensiones o se construye - directamente- desde una posición "defensiva": justifican permanentemente las razones de salida, la urgencia por hacerlo y los peligros de muerte que se corrían en caso de no irse. El mismo mecanismo se observa cuando el emigrado asegura haber vivido una experiencia emigratoria buena, sin demasiadas dificultades personales o laborales, o incluso con bienestar y ascenso social; esa situación privilegiada lo lleva a rechazar incluso la identidad de "exiliado". Porque para ellos, aceptar una condición de "víctimas" y la experiencia del "sufrimiento" distinta a la vivida en el exilio es imposible de comparar con lo que vivieron los desaparecidos, presos o torturados o, incluso, "exiliados internos". La misma lógica, pero con signo contrario, es la de quienes construyen la definición misma de exiliado desde la experiencia del sufrimiento:

"Entonces eso hizo que la vida en el exilio fuera muy dura... comenzar a vivir en un país que no conocía ni siquiera la lengua..., empezar de cero... Contrariamente a eso que muchos argentinos creen, la vida fue muy dura durante 10 años, sobre todo has-

24 Hemos desarrollado este tema en detalle en Franco, Marina: "Exilio y dictadura. Consideraciones en torno a algunas representaciones del exilio bajo el terrorismo de Estado", Anuario de Rosario, 20, segunda época, 2003-2004, Escuela de Historia/Homo Sapiens Ediciones, Rosario. 
ta que los chicos fueron grandes (...) Alors, c'était [Entonces era] en condiciones... sobre todo al principio... porque jamás pensamos nosotros en aquel momento que iba a durar 25 años, no sé cuantos, que sería definitivo ese exilio, yo pensé siempre que íbamos a volver a la Argentina. (...)

Lo único que yo quisiera remarcar es que el exilio es muy muy muy duro, a pesar... y sobre todo porque yo quedé muy ligada a la Argentina. Es una cosa increíble; nunca pensé que no iba a volver a la Argentina, y, sin embargo, en mis actos no lo hago..."25

Así, en todos estos casos, se autositúen fuera o dentro de la experiencia del exilio y de la categoría de exiliado, los entrevistados tienen necesidad de definir la situación y el concepto mismo de exilio a partir del dolor y la dificultad de la experiencia. ${ }^{26}$

Estos elementos hacen que frecuentemente la estructura misma de las narrativas y la forma de organizar el relato - además de su contenido explícito - tengan un sentido de autolegitimación, tendente a mostrar que el exilio es una "condena" y un "castigo", comparable a otras represiones sufridas por quienes se quedaron en el país. O, por el contrario, este proceso de autolegitimación se efectúa mostrando que el exilio es, en efecto, "una situación privilegiada" no comparable a la de quienes sufrieron directamente la represión. Además, es significativo que, en todos los casos, estas aclaraciones suelen ser espontáneas y formuladas al inicio mismo de la entrevista. Esto muestra hasta qué punto las representaciones sociales en circulación sobre el tema condicionaron la imagen del exilio y las propias representaciones que estos actores políticos tienen de sí mismos hasta el día de hoy.

\section{Los silencios}

Nuestra tercera constatación se relaciona con ciertos "silencios" selectivos de los relatos, con los límites experimentados en esa posibilidad de hablar y de ser escuchado. En este sentido, en los relatos hay varios huecos diferentes, cuyas características y razones intentaremos presentar aquí, dentro de la brevedad que impone el marco de un artículo.

25 J.V., París, 28 de marzo de 2003.

26 Aclaremos que en general el exilio es definido por nuestros entrevistados como una experiencia negativa sólo en el sentido del sufrimiento vivido - por lo doloroso de la experiencia en el exterior o por la sensación de la derrota en Argentina-, pero la condición de exilio en sí misma no tiene una carga simbólica negativa y la experiencia vivida tampoco es condenada. 
Hay un primer "hueco" en las narraciones de los antiguos emigrados políticos que es la omisión de las experiencias represivas directas vividas, o que son limitadas a una referencia mínima. Así, la desaparición de seres queridos, la tortura o el encarcelamiento son referidos con dificultad y sólo en la medida en que son hechos que "justifican" la decisión de emigrar o la expulsión del país. Es un dato que ya los especialistas de la Shoah habían señalado con respecto a los sobrevivientes de los campos de concentración: el pudor y la dificultad para hablar de aquellas experiencias que reducen el cuerpo y lo humillan deshumanizándolo. ${ }^{27}$ En nuestro caso, el hecho mismo de la violencia física estableció una barrera del pudor difícilmente franqueable por los entrevistados, y que, por supuesto, fue respetada por nosotros, en especial porque el entrevistado no había sido convocado para hablar de ello.

El segundo "hueco" de las narraciones, el más significativo de todos, tiene que ver con su vida pasada, previa al hecho migratorio y, en particular, a la militancia política. Por lo tanto, las reflexiones que siguen se refieren exclusivamente a quienes tuvieron trayectorias de actividad política significativa antes de la emigración.

Este aspecto es eludido en el relato de muchos de nuestros entrevistados, suponiendo con "alivio" que una "historia del exilio" no se interesa por la historia previa al momento de salida del país. Así, por ejemplo, la mayoría de los entrevistados no menciona la organización o grupo en el que militó antes de emigrar, ya sea por omisión absoluta o por referencias elusivas y vagas: "la organización", "yo era un militante social". De la misma manera, en el relato mismo de la experiencia emigratoria, en muchos casos la actividad política desarrollada en el exterior, sus conflictos, tensiones y lo vinculado a las identidades político-partidarias durante el exilio son silenciadas para enfatizar la actividad de "denuncia" o de "solidaridad". Muchas veces, tras horas de conversación - y avanzada la "negociación" de confianza que significa toda situación de entrevista- el entrevistado menciona su identidad política precisa o acepta hablar de ello, no sin ciertos gestos de incomodidad física o, por ejemplo, bajando el volumen de voz. En otros casos extremos, la negativa explícita a admitir toda identidad política, o a hablar de la actividad político-partidaria antes o durante el exilio (aun cuando, evidentemente, el entrevistador la conoce), permitió reconstruir la identidad de quien hablaba como "inocen-

27 Pollak, M.: L’expérience..., pág. 180. 
te" de toda sospecha posible. ¿Qué sospechas pueden pesar, entonces, sobre un exiliado? ¿Se trata de "olvidos", de "silencios" o de "memorias selectivas"?

En principio, este segundo tipo de "huecos" no coincidiría con el momento actual de la memoria, caracterizada por los procesos públicos de recuerdo y, más recientemente aún, por una auténtica explosión de las "memorias militantes" y un verdadero proceso general de toma de la palabra. Sin embargo, como decíamos, la dificultad para hablar del tema en la mayoría de los testigos sigue siendo muy fuerte. De todas formas, vale la pena señalar que desde el inicio de nuestras entrevistas hasta su finalización — es decir, entre abril de 2002 y diciembre de 2004 — hemos notado una evolución en ese sentido - un movimiento de ampliación de la frontera de lo decible-, y, muy en particular, en los testigos que volvieron a Argentina, donde ese proceso de "recuerdo" y "escucha" públicos es siempre más visible y posible de experimentar.

Ahora bien, es imprescindible explicar desde varias lógicas y lugares distintos los silencios de las narrativas de la emigración política. Creemos que un primer orden de problemas responde al espacio de lo estrictamente privado - aunque éste se realimente del espacio público como cualquier subjetividad individual - y se relaciona con un síntoma conocido de todas las situaciones traumáticas. Se trata de los sentimientos de culpa, y en particular para muchos, de la culpa por haber sobrevivido y haberse ido del país:

"A mí me costó mucho; hacer la especialidad en medicina, decirme que mi vida la iba a hacer aquí [Francia], tal vez... sentía como una traición de buscar trabajo, mejorar mis condiciones materiales, me decía que mis compañeros estaban presos, desaparecidos y que vivían muy mal en Argentina..." 28

El caso siguiente también es elocuente. G.S. era un militante del PRT que durante ocho años esperó, encarcelado, que le dieran el "derecho de opción" ${ }^{29}$ para salir del país y reunirse con su esposa que ya estaba refugia-

28 Entrevista con O.U., París, 23 de abril de 2003.

29 Este artículo de la Constitución Argentina (Art. n. ${ }^{\circ}$ 23) establece que en situación de estado de sitio el presidente de la Nación no puede fijar penas a los detenidos, pero sí otorgarles el derecho a salir del país temporalmente. Este derecho fue suspendido en 1976 y restituido en septiembre de 1977. Su aplicación exigía que el prisionero solicitara refugio en algún país extranjero y que fuera aceptado. De cualquier manera, la norma fue utilizada como sanción penal por su manejo discrecional, por el retardo en su aplicación y por utilizarse como una salida forzada y prolongada, dado que no permitía el regreso al país de los optantes bajo el riesgo del encarcelamiento inmediato. 
da en Francia con su hijo pequeño. Finalmente, G. cumplió su condena sin recibir nunca la opción y logró irse del país un año después de haber salido de la cárcel, cuando a inicios de 1983 los militares le levantaron la libertad vigilada con la que había vivido durante un año.

G.S.: Yo, si salía... si salía vivo, porque primero era salir vivo de la cárcel, y estaba en Rawson, porque veía a muchos compañeros míos, y yo mismo pasé por situaciones muy muy límites, sólo el azar hizo que yo no me tocara estar en otro lugar de donde yo estaba... Este... Yo pedía la opción pero me la rechazaban sistemáticamente, y siempre surgí.., siempre estaba la idea de que alguna vez me podían decir: "le damos la opción", entonces para mí... me podía ir a Francia. Lo mismo que yo no sabía era si a mí me daban la libertad en el país, en una situación de poder quedarme, si yo iba a irme o yo me iba a quedar. En ese caso, si yo no iba a ir, mi mujer iba a volver; y si mi mujer no iba a volver, era seguro que yo iba a ir. La disyuntiva era "¿qué pasa si no me dan la opción?". Yo, íntimamente, tenía mucho deseo de que me la dieran, este... ¿por qué? Porque... quería un poco de tregua en mi vida, no, no, yo había caído con 24 años, este... ya tenía más de 30, tenía un hijo de 8 años con el cual no había vivido, y el escenario del país se me hacía como mucho más difícil; por lo pronto me imaginaba un terreno muy inseguro, habíamos sufrido una derrota política muy importante, una derrota militar que también implica una derrota política (...) pensar en salir en libertad en Argentina, en ese marco, era una situación más desfavorecida que pensar a salir en Francia.

M.F.: ¿Pero esto no era algo que vos sintieras y que pudieras hablar o decir abiertamente?

G.S.: Claro. No. Por ahí con algún compañero... no es que hubiera alguna cosa persecutoria pero...

M.F.: No, entiendo; pero había algo que era pesado de decir...

G.S.: Pero aparte estábamos los que podíamos salir en libertad en cualquier momento, y estaban los que no podían salir en libertad, entonces (...) contar plata delante de los pobres frente a un compañero que está con una condena por 25 años, en una acción donde podría haber sido yo... Entonces decir: "Me voy a ir a Francia, me voy a comer quesos franceses, voy a ir a las playas donde las mujeres toman... [ríe]" iporque claro ésa era la fantasía! Además, en una cárcel, te imaginás, decís que... Uno se privaba... - -y me parece que está bien hacerlo, lo reivindico-, ... de decir: "Yo me voy a ir a Francia..." Habíamos caído por hacer una revolución en Argentina, ¡no podía ocho años más tarde decir: “¡me quiero ir a tomar sol a las playas!” Esteh... pero... íntimamente, sí: "Ahí está mi mujer, está mi hermano, mi hijo, muchos amigos, necesito una tregua en mi vida, volver a conectarme, qué pasa en el mundo hoy, qué es la Argentina, qué es mi organización, quién soy yo...”.30

$\mathrm{Al}$ igual que para otros que consideraron "impensable" la alternativa de salir con la figura legal de la "opción", este testimonio, atravesado por

30 G.S., Bs.As., 18 de agosto de 2004, el subrayado es nuestro. 
las sensaciones internas de la culpa y el deseo "inconfesable" de irse, da cuenta de algunas de las tensiones que el hecho de emigrar pudo producir y, por tanto, de la dificultad de los actores para situarse y construirse a sí mismos en ese acto. Es decir, irse del país, ser un emigrado, un exiliado, no podía tener connotaciones positivas cuando ello implicaba la culpa por los que se quedaban en el país, por los muertos y por abandonar una causa política.

Aclaremos rápidamente que, lejos de cualquier juicio moral, ético o religioso, consideramos el "sentimiento de culpa" en el sentido analizado por Michael Pollak, es decir, como un síntoma que expresa un malestar, y no una causa o una categoría de análisis. ${ }^{31}$ Por tanto, la culpa no conlleva en nuestro análisis una connotación de responsabilidad o de inocencia en sí misma, sino la manifestación de una incomodidad en la propia posición de exiliado.

Si el problema de la culpa ha sido muy tratado en relación con los sobrevivientes de la Shoah y mencionado en muchas situaciones de exilio, ${ }^{32}$ en este caso particular, la culpa por haber sobrevivido a los compañeros de militancia muertos pudo llevar al silencio y, en particular, a no mencionar el comienzo de la experiencia vital que terminó con la experiencia de la represión: el compromiso político. En otras ocasiones, la culpa por sobrevivir puede transformarse directamente en el cuestionamiento interno de toda la experiencia política vivida en sí misma y, por tanto, pudo haber llevado a la elección de un silencio auto-protector. ${ }^{33}$

Otro punto desde donde pueden explicarse los silencios es el espacio público y, nuevamente, se relaciona con las representaciones del pasado que todavía influyen sobre ciertos momentos de la experiencia de los actores: en particular, la llamada "teoría de los dos demonios".

31 Pollak, M.: L'expérience..., pág. 250

32 Este sentimiento de culpa ha sido revelado por todos los trabajos psico-sociológicos sobre exilio y, en particular, por Ana Vásquez y Ana María Araujo, en su investigación sobre los exiliados del Cono Sur latinoamericano en Francia. (Vásquez, Ana, y Araujo, Ana María: Exils latino-américains: la malédiction d'Ulysse, CIEMI-L'Harmattan, París, 1988, págs. 46-49). Sobre la culpa en sobrevivientes de la Shoah: Agamben, G.: Lo que queda de...; Bettelheim, Bruno: Survivre, Laffont, París, 1979; Levi, Primo: Si esto es un hombre, Muchnik editores, Barcelona, 2001; Pollak, M.: L'expérience....

33 La culpa por haber sobrevivido también podría ayudar a explicar el primer silencio mencionado con respecto a las experiencias de violencia directa (prisión, tortura) vividas por algunos exiliados, ya que su omisión en los relatos puede también ser otra forma de evitar la pregunta y el malestar por haber sobrevivido a esas experiencias extremas frente a quienes no lo hicieron. 
En la primera etapa pos-autoritaria, dos hitos históricos marcaron el período y significaron, en su momento, actos fundacionales de la democracia argentina de 1983: la Comisión Nacional por la Desaparición de Personas (CONADEP), creada por el presidente Raúl Alfonsín, que tuvo a su cargo la investigación sobre las desapariciones que derivó en el Juicio a las Juntas Militares en 1985 y la publicación de su informe Nunca Más. Esta obra, muchísimas veces reeditada, instalaba una imagen compleja del período precedente al referirse a un "terror de extrema izquierda" al que los militares habrían respondido con "un terrorismo infinitamente peor". ${ }^{34}$ A su vez, la sociedad en su conjunto quedaba libre de cualquier responsabilidad social, era víctima inocente del terrorismo. Vinculada con esta lectura, por aquellos años y hasta mediados de los noventa, por medio de una variedad de memorias y discursos públicos en circulación, las imágenes hegemónicas del pasado eran las de una "guerra sucia", simbolizada en esta metáfora de los "dos demonios". ${ }^{35}$ Esta visión sostenía que en los setenta se habían enfrentado dos enemigos, dos terrorismos en igualdad de condiciones: la guerrilla y los militares, y ambos eran igualmente responsables de la violencia y el "horror". ${ }^{36} \mathrm{Si}$ bien sus orígenes se remontan incluso a períodos anteriores al golpe militar de 1976, a partir de 1983 esta interpretación bipolar fue mantenida y estimulada desde distintos espacios públicos, tanto por intelectuales antes vinculados a los movi-

34 Nunca más, Eudeba, Buenos Aires, 1999 [1984], pág. 7.

35 La construcción de la imagen de una guerra entre "dos demonios" no se sostiene desde la misma lógica cuantitativa: las dos principales organizaciones armadas no llegaban a reunir entre ambas más de 1.300 miembros armados — tomando la cifra por lo alto- y nunca existió la amenaza real de una toma del poder exitosa por parte de estas organizaciones. De la misma manera, una de ellas, el ERP, ya había sido prácticamente destruida antes del golpe militar de 1976. Por lo tanto, la imagen del poder y potencial bélico de este enemigo subversivo fue creada luego por las Fuerzas Armadas para justificar sus propias acciones (Vezzetti, H.: Pasado y presente..., págs. 76-77, 121-128). Sobre la teoría de los “dos demonios", véase Acuña, Carlos, y Smulovitz, Catalina: "Militares en la transición argentina: del gobierno a la subordinación constitucional", en Acuña, Carlos, et al.: Juicio, castigos y memorias. Derechos Humanos y justicia en la política argentina, Nueva Visión, Buenos Aires, 1995, págs. 19-99; González Bombal, Inés: “'Nunca Más’. El Juicio más allá de los estrados”, en Acuña, et al.: Juicio, castigos y memorias..., págs. 193-215; Vezzetti: Pasado y presente..., págs. 109-146.

36 Esta lectura puede remontarse incluso al período previo a la dictadura militar, antes de 1976, cuando circulaban algunos discursos mediáticos y políticos condenatorios tanto de la guerrilla como de los militares golpistas. Por otra parte, las mismas fuerzas en cuestión - militares y organizaciones armadas - consideraron durante gran parte del período que estaban enfrentadas en una guerra y esta interpretación sólo fue modificada por las segundas cuando adquirieron conciencia de la "derrota", a fines de los años setenta. 
mientos de guerrilla ${ }^{37}$ como por los mismos miembros del gobierno de Alfonsín. ${ }^{38}$

De esta manera, la persistencia y hegemonía de esta representación del pasado presente durante largos años en la sociedad argentina puede impedir todavía que los testigos se refieran a ciertos aspectos políticos de la experiencia vivida, pues sobre ellos pende la sospecha implícita de la responsabilidad de la militancia en la generación de la violencia que condujo al golpe de Estado.

Incluso el mismo discurso militar, y de buena parte de la población, que durante el período dictatorial y aún después aludía a las víctimas diciendo: "algo habrán hecho..." puede seguir desempeñando un rol sustancial en lo que se considera transmisible, o no, frente al juicio del interlocutor. Es por eso que, todavía, en la actualidad, esa parte del relato del pasado previo a la emigración lucha entre lo decible y lo no-decible en ciertos protagonistas de la emigración política.

Es importante recordar aquí que también la antropóloga Ludmila da Silva Catela indica esta misma situación sobre el relativo silencio de otros portadores de memoria considerados como voces "menos legítimas": los antiguos presos políticos. Así, señala la investigadora que en cuanto se proyecta sobre ellos la culpa por haber sobrevivido y militado —en particular la violenta—, estos actores resultan silenciados. ${ }^{39}$ Ratificando esta misma

37 Es el caso de Pablo Giussani, autor de uno de los libros más críticos sobre Montoneros (Montoneros. La soberbia armada, 1984), considerado uno de los promotores de esa teoría a partir de diversos artículos aparecidos en el diario La Razón desde 1985 (Gasparini, Juan: Montoneros. Final de Cuentas, de la Campana, Buenos Aires, 1999 [1988] y Jensen, Silvina: "Del viaje no deseado al viaje de retorno. Representaciones del exilio en Libro de Navíos y Borrascas y Tangos. El exilio de Gardel", en Jelin, Elizabeth, y Longoni, Ana: Escrituras, imágenes y escenarios ante la represión, Siglo XXI, Buenos Aires, 2005, págs. 167-202).

38 Dante Caputo, canciller de Alfonsín, decía en febrero de 1984 ante la Comisión de Derechos Humanos de la ONU: "en una juventud frustrada encontraran eco los apóstoles de la violencia, los grupos terroristas de distinto signo que preconizaban como método de acción el atropello de los derechos a la vida, a la integridad física y a la libertad. Fue así como los terroristas, movidos por el delirio de una supuesta liberación (...) cuyo único resultado consistiría en desencadenar una terrible acción represiva, ejecutada por aparatos de represión estatal y paraestatal que arrasaron las instituciones y las libertades de nuestro país. (...) La infantil especulación dialéctica, según la cual para alcanzar el paraíso debe pasarse primero por el infierno, condujo de este modo al imperio de una represión basada en métodos igualmente condenables." (Ministerio de Relaciones Exteriores y Culto, "Discurso pronunciado por el señor ministro de relaciones exteriores y culto de la República Argentina, licenciado Dante Caputo, ante la Comisión de Derechos Humanos en Ginebra”, Ginebra, 27 de febrero de 1984.

También Vezzetti en Pasado y presente... sostiene que Alfonsín estimuló esta lectura al someter a juicio por igual a las cúpulas de Montoneros y ERP y de las Fuerzas Armadas.

39 Da Silva Catela, Ludmila: No habrá flores en las tumbas del pasado, Ediciones Al Margen, Buenos Aires, 2001, pág. 282 y ss. 
interpretación, una ex prisionera política manifiesta con una inmensa carga emotiva las selecciones de las memorias sociales y del espacio público para expresar ese pasado:

"Es como las Madres [de Plaza de Mayo] son puras y blancas, los Hijos también. Sigue habiendo una cosa de ellas, madrecitas; ellos, inocentes, y nosotros, los representantes de los que no son ni tan puros, ni tan blancos. Así lo toma la sociedad y acepta a Madres y a Hijos. Nosotros no tenemos lugar." ${ }^{40}$

Una tercera lógica explicativa remite a las prácticas mismas de militancia política previa de muchos de estos actores: la cultura del secreto, propia de una actividad política prohibida que se realiza en la "clandestinidad", tal como era el caso de las militancias en las organizaciones de izquierda, armadas o no, durante los años sesenta y cada vez más a partir de los setenta. ${ }^{41}$ El secreto fue una condición esencial con la que estos actores se formaron políticamente o ingresaron en la cultura política, sobre todo si se tiene en cuenta que se formaron cuando aún eran muy jóvenes. Además, si el secreto fue una marca esencial de aquella militancia, luego, progresivamente, en la medida en que la represión se fue acentuando-a partir de 1975 y más aún después del golpe de Estado—, el secreto se transformó en la condición primera y última de la acción política y, en muchos casos, pudo ser la condición de la supervivencia - la propia y la de los compañeros- . De la misma manera, un sistema represivo basado en la tortura dio a la información un valor tan primordial que su lado opuesto, "no hablar", adquirió un sentido político y ético superior a cualquier otro. Así, creemos que las marcas emocionales de estas prácticas políticas, marcadas a fuego más tarde por la represión, se reflejan aún hoy en las narrativas de muchos emigrados políticos.

Otra cuarta posibilidad que explica los silencios puede ser analizada a través del problema del anonimato de las fuentes. Este es un punto de observación privilegiado sobre el que nos detendremos en particular. $\mathrm{La}$ "negociación" inicial con los entrevistados dejó al descubierto que el problema de la preservación de la identidad resultaba una cuestión esencial

40 Calvo, Adriana: "Campos", en Gelman, Juan, y Lamadrid, Mara: Ni el flaco perdón de Dios/Hijos de desaparecidos, Planeta, Buenos Aires, 1997, pág.113.

41 Debe tenerse en cuenta que durante gran parte del período el país vivió bajo regímenes autoritarios militares o en condiciones de restricción o prohibición de la actividad política: entre 1966 y 1972 durante la dictadura de Juan Carlos Onganía y sus sucesores, y luego, tras un breve período de apertura en 1973, las principales organizaciones revolucionarias fueron rápidamente declaradas ilegales, primero el PRT-ERP y luego Montoneros. 
que debía ser subrayada - y reasegurada muy enfáticamente- a muchos entrevistados. En algunos casos, el anonimato era la garantía imprescindible para acceder a la entrevista; en otros, el entrevistado confesaba con orgullo que todo podía ser dicho "con su nombre y apellido". Incluso, en dos únicos casos la garantía escrita del anonimato no fue suficiente y los entrevistados se negaron a ser grabados. El primero de ellos corresponde a una emigrada política argentina - actual residente en una pequeña localidad del interior de Francia- cuya extrema tensión en torno a lo "no decible" de la militancia política y el silencio absoluto sobre su pasado - aun en su entorno familiar- dejó a la vista fuertes autocensuras. En el otro caso, se trataba de un militante político francés que, habiendo sido miembro fundador y muy activo de un comité de solidaridad de izquierda con Argentina, se negó a grabar la conversación.

Ahora bien, ¿qué garantiza realmente el anonimato? En muchos casos su importancia se vincula con no dar a conocer ciertas experiencias del pasado que podrían comprometer la "imagen" actual de la persona o de otras personas mencionadas en su relato. De este modo, muchos entrevistados - hoy profesionales reconocidos- prefieren que su vínculo con aquella "historia de los setenta" no sea público y por ello optan por el anonimato o por silenciar ciertas partes de su experiencia. Volviendo entonces a lo ya señalado sobre los estigmas públicos, el pasado aparece como un portador de vergüenzas, culpas y sospechas y el presente como un vehículo de sanción moral.

Sin embargo, en otros casos, no es el presente el que autocensura, sino el mismo pasado: así, en ciertos relatos es el mismo miedo el que exige los resguardos de identidad o lleva a silenciar ciertos datos. Además, paradójicamente fueron en cierta medida los antiguos emigrados políticos entrevistados en Francia quienes mayores temores manifestaron, demostrando que los "fantasmas" del Estado represivo han quedado más atrapados en quienes no regresaron al país y no vivieron in situ las alternativas del proceso post-autoritario y las transformaciones actuales de la sociedad argentina. Inclusive, también a la hora de testimoniar, ciertos ex militantes franceses de izquierda expresaron su temor ante la inestabilidad de la vida política argentina, la acción de los sistemas de información y control y la incertidumbre sobre quién podría leer o manipular ciertos archivos e informaciones.

Todos estos ejemplos muestran hasta qué punto — aún para muchos que no fueron víctimas de la represión física directa— las marcas del pasa- 
do han quedado inscriptas en el cuerpo, más allá de toda constatación racional. Y, también, como el pasado está lejos de haber quedado atrás, siendo una realidad que aún se conjuga en presente para muchos y que por eso genera silencios y autocensuras.

\section{Posiciones narrativas}

Otro aspecto relevante para nuestro análisis son las posiciones narrativas adoptadas por los actores entrevistados. Es imposible extraer conclusiones generales al respecto, pero a lo largo de nuestro trabajo hemos encontrado algunos diferentes tipos de relatos que merecen destacarse. Entre ellos, por ejemplo, narraciones "heroizantes, intimistas, generalizantes, minimizantes". Uno de los casos más frecuentes es el del testigo que no cree tener "nada importante para decir", porque considera su vida "poco generalizable" o "poco interesante". Muchas veces le ocurre a individuos que no tuvieron demasiada actividad política en el período de emigración o que no consideran haber tenido una actuación colectiva; incluso, también le sucede a individuos que, habiendo tenido actividad, no consideran que sus circunstancias personales de emigración hayan sido muy "duras". Esto revela que la otra posición de narración posible, desde la condición de "víctima perseguida", se presenta como la más "legítima" para la transmisión de la experiencia, tanto para quienes la detentan explícitamente como para quienes no pueden demostrarla. Aclaremos que, en cualquiera de esos casos, depende siempre del entrevistador demostrar el interés que posee la experiencia de emigración, en tanto vivencia individual y única, ya que no hay un recorrido emigratorio legítimo o más válido que otros.

En otras narraciones, en general fuertemente asociadas a experiencias de militancia político-humanitaria en Francia (no a la militancia previa en la Argentina), la construcción del relato puede adquirir un tono épico de algunos aspectos. En el ejemplo que sigue, la enunciación deja a la vista una estrategia narrativa en la que el actor se constituye como portador de la memoria grupal:

"Bueno vamos a contar las experiencias del exilio en Francia. (...) En general, el exilio en Francia tuvo características un poco diferentes, en primer lugar era gente dispuesta a apechugar con un medio que no lleva la lengua de origen. (...) Y yo reivindico totalmente aquello que hicimos en el Comité. Aquello que hicimos en el Comité es una declaración del más alto nivel consciente y político, que todavía los partidos 
políticos de izquierda acá [Argentina] tendrían que considerar. (...) En ese sentido puede ser muy constructivo el testimonio que yo estoy dando porque significa que frente a una realidad, en otro ámbito, realmente las ideas se aclararon." ${ }^{42}$

A pesar del carácter único de este ejemplo por su nivel de amplificación extremo, nos permite ilustrar bien un rasgo frecuente de las narrativas que es la exaltación de algunos aspectos como la actividad de denuncia humanitaria desarrollada. En muchos de estos casos, además, la narración se estructura "en nombre de un valor general", ${ }_{43}$ utilizando las formas gramaticales impersonales de quien relata una experiencia colectiva para su registro: "se hizo mucho".

En un sentido parcialmente opuesto, otra posición narrativa hallada se caracteriza por un punto de vista crítico de la propia experiencia - en grados muy variables, desde el humor, el enojo hasta el cinismo-, por ejemplo: "El exilio es una cosa muy jodida y si los argentinos tenemos fama de... de... producir divisiones, pelearnos, en el exilio es mucho peor"; "El exilio era un zoológico". ${ }^{44}$

Más allá de revelar experiencias diferentes, estas posiciones narrativas revelan las variables desde las que cada individuo construye su relato del pasado. Lo importante es que el posicionamiento narrativo - que en general antecede al relato- prefigura ya una cierta selectividad del recuerdo. Así, por ejemplo, quien relata desde la posición heroica tenderá a enfatizar lo realizado en términos de la denuncia internacional por las violaciones de los derechos humanos, "olvidando" u ocultando el nivel de conflictividad interna de los comités de exiliados, por ejemplo. Por otro lado, quien lo hace desde una posición crítica desechará toda la experiencia por considerarla inútil; o quien lo hace desde una mirada idealista enfatizará su fácil adaptación al nuevo medio, la rápida obtención de trabajo y la sensación de libertad, obviando circunstancias de maltrato en su condición de extranjero, la nostalgia o la incertidumbre por el "país lejano", la pérdida de los lazos afectivos, etc.

$\mathrm{Si}$ vinculamos algunas de las posiciones narrativas con el tema los silencios, se hace evidente que una parte de los relatos del pasado todavía está dividida entre el campo de los "demonios culpables" y las "víctimas

42 U.C., Buenos Aires, 9 de septiembre de 2002.

43 La categoría es de Michael Pollak, que opone esos relatos a los "en nombre de sí mismo" (Pollak, M.: L'expérience..., págs. 230-244).

44 Entrevistas a M.L., París, 2 de abril de 2003; J.G., Buenos Aires, 23 de agosto de 2003, respectivamente. 
inocentes" allá por los años ochenta. Así, la militancia política, socialmente censurada y responsabilizada como un "demonio" causante del terrorismo de Estado, es ocultada o minimizada por los testigos, mientras que la lucha por los derechos humanos es recordada, y a veces exaltada, porque en el imaginario social su carácter humanitario y no partidario fue capaz de trascender la política para defender a las víctimas de ese terrorismo.

\section{Algunas reflexiones finales}

En relación con la experiencia misma del exilio, el análisis de las formas narrativas, los datos no verbales, los silencios y tensiones muestran hasta qué punto el procesamiento colectivo y público de la historia reciente ha condicionado la posibilidad de hablar, de ser escuchado y la selección de lo que es transmisible para los testigos actuales.

Es imprescindible señalar que el ángulo de observación elegido por nosotros no pretende ser reduccionista. Por el contrario, su uso como variante explicativa debería ser acompañado por el estudio de las formas de procesamiento psico-individual de las experiencias traumáticas. De esta manera, tanto las formas narrativas como los silencios también pueden ser comprendidos en función de los tiempos psicológicos necesarios para querer recordar y poder hablar. De igual forma, el paso de los años, la conciencia de la edad y la necesidad de transmisión generacional agregan otros imperativos a esa necesidad.

Mientras que para buena parte de los exiliados — cualquiera que sea su experiencia personal- la evocación de su experiencia de destierro es inseparable de la referencia a la muerte y a la represión en Argentina, como caras de un mismo prisma, la sociedad argentina lo está descubriendo ahora. Para quienes protagonizaron esa historia, esa relación está siempre presente y es constitutiva de su historia como sujetos:

'Hubiera querido que esto no pasara. Que no pasara. Y en el fondo, si yo estoy diciendo
'que esto no pasara', es porque... yo no hubiera querido el exilio. Cuando yo hablo de
exilio, aparte del sentimiento individual que yo pude haber tenido, el haber dejado mi
país... cuando yo digo 'exilio', se me viene a la cabeza el cuco de los treinta mil desapa-
recidos. Por eso digo que yo hubiera querido, desde lo más profundo de mi corazón o de
mi mente, de mi ser, que el exilio no hubiera existido para mí. Hubiera significado que
no hubieran existido los treinta mil desaparecidos. Eso no lo podemos recuperar más.".

45 Entrevista con R.H., París, 9 de mayo de 2003. 
A pesar de que este proceso está en permanente movimiento, y últimamente se ha abierto en gran medida la posibilidad de hablar y el reconocimiento público de la figura del exiliado, el tema está lejos de estar saldado. Así, la sobrecarga de sentidos, muchas veces contradictorios, que se tensan en las narrativas de los entrevistados, expresan las alternativas de estos procesos, con sus idas y sus vueltas.

Por otra parte, el lento proceso de modificación de la representación pública del exiliado, en tanto portador legítimo del pasado, está teniendo, a su vez, una incidencia directa sobre las representaciones que los propios actores tienen de sí mismos, y contribuye a facilitar el proceso de toma de la palabra. Pero no debe generar falsas ilusiones. Basta preguntar a los antiguos emigrados políticos si en su vida cotidiana hablan abiertamente de su estadía en el exterior o de las razones por las que se fueron, para que la respuesta general sea "No", más allá de la selección de personas y circuitos en los que sí considera posible hacerlo. De la misma manera, basta evocar el enorme silencio que rodea la militancia política previa al exilio para observar que esta toma de la palabra está aún presa de fuertes recortes en torno a lo que se considera decible y transmisible. Es decible la condición de exiliado en tanto víctima y a la vez actor de la denuncia de violaciones a los derechos humanos, pero es más difícilmente decible la condición de exiliado como militante político, con una historia, un compromiso y una experiencia vivida en torno a ello.

Y esto nos remite a un problema de fondo: en Argentina hay, todavía, muchos temas que son tabú. La actual explosión de memorias militantes ha abierto una brecha, pero para una gran cantidad de gente, anónima y silenciosa, ese pasado sigue siendo un indecible.

Recibido el 2 de marzo de 2006

Aceptado el 10 de junio de 2006 